\title{
The effect of hedgerow density on habitat quality distorts species-area relationships and the analysis of extinction debts in hedgerows
}

\author{
Kathrin Litza (D) Martin Diekmann $(\mathbb{D}$
}

Received: 2 October 2019/Accepted: 4 April 2020/Published online: 15 April 2020

(C) The Author(s) 2020

\begin{abstract}
Context Hedgerows are highly important for maintaining the biodiversity in deforested landscapes. Especially for habitat specialists such as several forest plants they can provide important refuge habitats.

Objectives This study aims to examine whether there is an extinction debt for forest plants in hedgerows.

Methods In a study area in Northern Germany that had lost $47 \%$ of the hedgerow network over the past 120 years, hedgerows were mapped for the presence of forest vascular plants. In a multi-model approach, we compared the explanatory power of present and historical landscape variables and habitat quality on diversity patterns.

Results The change in landscape configuration had no effect on the species richness of forest plants in hedgerows, i.e. there was no sign of an extinction debt. The best explanatory variable was the hedgerow width with more species found in wider hedgerows. This demonstrates the importance of including local habitat variables in the study of extinction debt. For ancient woodland indicator species models including both the landscape configuration and habitat variables were superior to simple models. The best models included
\end{abstract}

K. Litza $(\bowtie) \cdot$ M. Diekmann

Vegetation Ecology and Conservation Biology, FB2, University of Bremen, Leobener Straße 5, 28359 Bremen, Germany

e-mail: kathrin.litza@uni-bremen.de the historical distance to the nearest forest, suggesting an extinction debt. Counterintuitively, a high density of hedgerows had a negative influence on species richness, most likely because hedgerows are narrower in areas with higher densities due to land-saving measures by farmers. There was also a negative correlation between hedgerow density and the hedgerow proximity to forests.

Conclusions The effects of important covariates may obscure species-area relationships and undermine extinction debt analyses.

Keywords Extinction debt $\cdot$ Habitat loss $\cdot$ Hedgerow density $\cdot$ Historical vegetation ecology $\cdot$ Multi-model approach $\cdot$ Species-area relationship

\section{Introduction}

Habitat loss is one of the main threats to biodiversity (Sala et al. 2000; Dirzo and Raven 2003). When habitats are destructed this has a negative influence on species diversity, mainly due to a reduced carrying capacity of the habitat, stronger edge effects and an increased probability of extinction by stochastic processes. However, a decline in species numbers will not always occur immediately after habitat reduction but might occur with a time-lag (Tilman et al. 1994). When species have long generation times, 
a population can persist for decades or longer even though regeneration is lacking. In this way species are expected to go locally extinct even if no further habitat change occurs. This time-delayed loss of species is called the extinction debt, a concept which has received increasing attention in recent years (e.g. Tilman et al. 1994; Vellend et al. 2006; Kuussaari et al. 2009; Jackson and Sax 2010; Kolk and Naaf 2015). When species have long relaxation times, i.e. the time delay for predicted extinction to take place after a habitat has been altered or reduced, the extent of species loss may be underestimated. This poses a challenge for conservation efforts because the effect of habitat reduction often goes unrecognised (Jackson and Sax 2010). It is therefore important to study the extinction debt across different habitats and species groups in order to counteract habitat loss as long as species have not gone extinct.

Theory suggests that the likelihood of a time-lagged extinction is stronger for species with a high persistence, long generation times, and dispersal limitations (Kuussaari et al. 2009). A precondition is that species depend on a specific habitat type and are affected by the spatial configuration of this habitat. Forest plants are therefore prone to show an extinction debt, as they are dependent on woody habitats, which are strongly fragmented in large parts of Europe, and are known to have slow metapopulation dynamics (Kolb 2008; Brunet et al. 2011). Among forest specialists, the subgroup of ancient woodland indicator species (AWI, Schmidt et al. (2014)) is especially interesting to study in this context. These species indicate woodlands of a high conservation value and are likely to exhibit an extinction debt because of their low dispersal capacities (Kolk and Naaf 2015).

Until now, the presence of an extinction debt for forest specialists was examined for true forests (e.g. Vellend et al. 2006; Kolk and Naaf 2015) but not for other wooded habitats such as hedgerows, which are semi-natural linear habitats that form wooded networks across the landscapes in Central and Western Europe. They were originally set up in the eighteenth and nineteenth centuries as living fences but have been severely reduced in size during the agricultural intensification of the twentieth century (Deckers et al. 2005). We studied an area in which $47 \%$ of the network was lost within 120 years (see "Methods" section and Table 1 of this article for more details on the hedgerow loss). When intact, hedgerows can provide ecosystem services such as water purification, erosion reduction and pest regulation (Van Vooren et al. 2017), and may have an ecological effect disproportionately larger than their size (Poschlod and Braun-Reichert 2017). For specialised species that are dependent on wooded habitats, such as forest vascular plants, they can form migration corridors (Corbit et al. 1999; Roy and de Blois 2008; Wehling and Diekmann 2009b; Closset-Kopp et al. 2016) as well as refuge habitats (Endels et al. 2004; Wehling and Diekmann 2009a). This is especially important in areas that have been largely deforested with only fragmented forest patches left.

Landscape properties such as the connectivity of the surrounding network (Roy and de Blois 2008; Ernoult and Alard 2011; Paal et al. 2017) and the proximity to forests (Corbit et al. 1999; Litza and Diekmann 2019) have been shown to influence the number of forest specialists in hedgerows. Consequently, an area reduction of the hedgerow network as well as further destruction of the remaining forest fragments is expected to lead to a decrease in forest species richness. Besides habitat area and connectedness, the habitat quality also affects the diversity of forest plants in hedgerows (Adriaens et al. 2006; Paal et al. 2017). Previous studies have found several habitat conditions to be of importance, e.g. the prevailing soil conditions, particularly nutrient availability and pH (Critchley et al. 2013; Litza and Diekmann 2017, 2019). Additionally, the hedgerow structure has been repeatedly shown to be one of the key factors influencing the species assemblage, with wider hedgerows leading to more forest specialists due to a more favourable and stable microclimate (in terms of solar radiation, wind and temperature) (e.g. Sitzia 2007; Roy and de Blois 2008; Closset-Kopp et al. 2016; Litza and Diekmann 2019).

There are different ways of studying extinction debts and the choice of method depends on the study habitat and the available information. Historical data of species distributions is scarce which is why the most commonly used approach is to compare the influence of the past vs. present habitat configuration on today's species distributions (Kuussaari et al. 2009). If the current species occurrences are better explained by the past than by the present habitat configuration, an extinction debt is invoked. This configuration is often expressed as the area (when the influence of habitat loss is studied) or the connectivity of the habitat 
Table 1 Landscape and habitat variables included in the models

\begin{tabular}{llll}
\hline & Mean & Range & Variable group \\
\hline Present hedgerow density (m/ha) & 62 & $21-122$ & PL, PLAF \\
Present distance to nearest forest (m) & 500 & $27-1450$ & PL \\
Present distance to nearest ancient forest (m) & 720 & $32-1989$ & PLAF \\
Historical hedgerow density (m/ha) & 116 & $32-184$ & HL \\
Historical distance to nearest forest (m) & 664 & $15-1987$ & HL \\
Hedgerow width (m) & 4.5 & $2.3-7.5$ & HQ \\
pH & 4 & $3.2-7.0$ & HQ \\
\hline
\end{tabular}

The landscape composition was digitised as found on historical maps (1877) and present maps (2004). The hedgerow density was measured in a radius of $500 \mathrm{~m}$ around the investigated hedgerows $(\mathrm{n}=89)$

Variable groups: $P L$ present landscape, $P L A F$ present landscape with distance to nearest ancient forest, $H L$ historical landscape, $H Q$ habitat quality

patches (when habitat fragmentation is assessed). Fahrig (2003) underlined the importance of separating the effects of habitat loss and fragmentation, but as hedgerows are linear landscape elements these two variables are strongly correlated and the assessment of one also expresses the other. The fundamental assumption behind the concept of extinction debt is a positive species-area relationship, meaning that habitat destruction has a negative impact on species number. Challenges for studying the extinction debt may arise when habitat destruction is difficult to quantify or if other variables distort the positive species-area relation. This has not been covered by research until now. Many studies of extinction debts only include landscape variables (e.g. Vellend et al. 2006; Cousins et al. 2007), but Kolk and Naaf (2015) demonstrated for forests that it is very important to also consider measures of habitat quality to not overor underestimate the effect. Our study aims to demonstrate that covariates can impede disentangling the effects of habitat loss from effects of changing habitat quality and, consequently, studying the extinction debt.

We hypothesise that (1) the species number of forest specialists in hedgerows can better be explained by past than by present landscape configuration, i.e. that there is an extinction debt, (2) ancient woodland indicator species show a larger extinction debt than other forest species, and (3) habitat quality distorts the analysis of the effects of landscape variables on species richness.

\section{Methods}

Study area

The study area comprises the Schleswig-Holstein Uplands which are located in the east of the federal

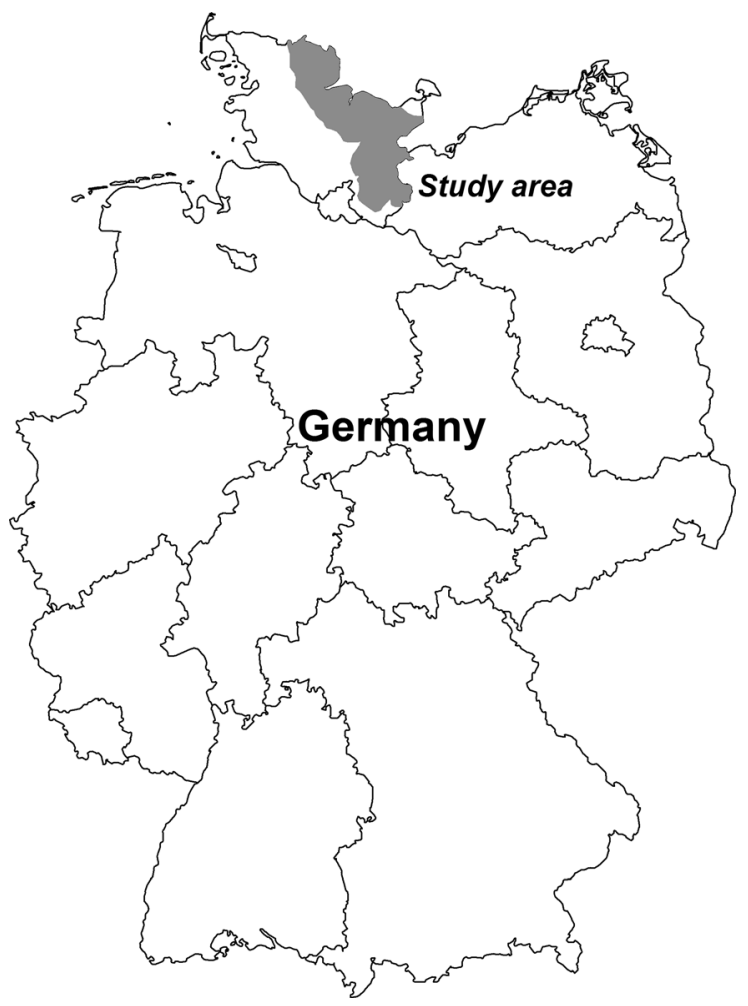

Fig. 1 Map displaying the study area in the east of the federal state of Schleswig-Holstein, Germany 
state of Schleswig-Holstein, Northern Germany (Fig. 1), and is characterised by a Young Drift morainic landscape. The climate is suboceanic with an annual precipitation of $770 \mathrm{~mm}$ and a mean annual temperature of $8.9{ }^{\circ} \mathrm{C}$ (DWD 2015).

The main land use in the study region is agriculture $(1,088,390$ ha $=68.9 \%) \quad$ while only $10.3 \%$ $(162,014 \mathrm{ha})$ are covered by forests (Statistikamt 2018). About half of the forests can be characterised as being ancient i.e. older than 200 years (Glaser and Hauke 2004). The estimates for today's hedgerow length vary between 44,915 km (Müller 2013), $68,281 \mathrm{~km}$ (MLUR 2005) and 73,400 km (Jungelt 2016). Based on this, the land cover by hedgerows can roughly be estimated. If the most widely used estimate of total hedgerow length of $68,281.2 \mathrm{~km}$ is multiplied by the mean hedgerow width in the study area of $4.5 \mathrm{~m}$ (Table 1), this sums up to an area covered by hedgerows of as much as 30,726.5 ha (1.9\%).

The establishment of hedgerows has a century-long tradition in Europe. Some hedges can be dated back more than 1000 years (Pollard et al. 1974; Stamm and Welters 1996) while most of the hedgerows in Central and Western Europe were established in the eighteenth and nineteenth centuries (Weber 1967; Pollard et al. 1974). As part of the Enclosing Acts, they were created as living fences that surrounded fields, marked boundaries and restrained the livestock. They also supplied fruits and were important sources of firewood and timber through periodical coppicing. Even though farmers do not depend on these features of hedgerows anymore, regular management is required until today to maintain the habitat. Poorly managed hedgerows are threatened to lose their important ecological functions and show a decrease in species diversity (Staley et al. 2013). In the study area, the land-owners are until today obliged by law to manage the hedgerows in an appropriate manner (regulations in MELUR 2017). During the 1950s to 1980s the land consolidation process in Central and Western Europe had the purpose of generating larger agricultural fields that could be managed more efficiently. In the course of this process, large parts of the hedgerow network were removed, locally more than $70 \%$, while only few hedgerows were newly planted to compensate for those measures (Kellerhoff 1984). The most frequent shrub species found in hedgerows are Corylus avellana, Prunus spinosa, Sambucus nigra and Rubus fruticosus agg., while the tree layer is most often formed by Quercus robur.

\section{Data sampling}

We investigated 89 hedgerow plots in total. Of those, 42 were sampled in summer (June and July) 2015 and again in April 2016. Another 32 were investigated in May 2016 and the remaining 15 in spring (April and May) 2017 and summer (July) 2017. The plots had a length of $70 \mathrm{~m}$ and were confined by the borders of the adjacent fields, i.e. included the field margins in the analysis. The surveys recorded presence/absence data of all forest specialists (classified by Schmidt et al. (2011) as 1.1 'largely restricted to closed forests' and 1.2 'preferring forest edges and clearings'). We distinguished the ancient woodland indicator (AWI) species as a subgroup (Schmidt et al. 2014). These are forest specialists that have particularly low dispersal capacities, are thus mainly confined to habitats with a long stability in the landscape and indicate habitats of a high conservation value. All investigated hedgerows were already present on maps from 1877 to 1879 and can thus be considered as ancient (Litza and Diekmann 2019). Recent hedgerows were shown to have not yet attained equilibrium diversity (Litza and Diekmann 2019) and were therefore excluded from the sampling.

We measured the width of the shrub layer once per plot at a representative point close to the plot centre. Only hedgerows with a minimum height of $2 \mathrm{~m}$ were included in the sampling to exclude newly coppiced hedgerows. Hedgerow width is known to be an important proxy for local habitat quality (ClossetKopp et al. 2016; Litza and Diekmann 2019), but it cannot be measured directly after coppicing, i.e. the removal of the shrub layer. One soil sample per plot was taken in the centre of the plot to determine the $\mathrm{pH}$ values. For the analysis, the soil was air-dried and sieved in the laboratory, and $10 \mathrm{~g}$ of soil were mixed with $25 \mathrm{ml}$ of $0.1 \mathrm{M} \mathrm{CaCl}_{2}$. After $1.5 \mathrm{~h}$ of shaking the $\mathrm{pH}$ was measured using a $\mathrm{pH}$ meter with glass electrode.

Present and historical landscape properties

Spatial analyses were carried out in QGIS (QGIS Development Team 2016) and $R$ (version 3.6.1, R Foundation for Statistical Computing, Vienna, AT) using the package 'rgeos' (Bivand and Rundel 2018). 
We used the maps of the 'Preußische Landesaufnahme' $(1: 25,000)$ by the Prussian government (1877-1879, hereafter referred to as from 1877), which are likely to reflect the historical peak in hedgerow density, to gather information about the former landscape composition. The newest maps covering the complete study area were published in 2003-2008 (Topographische Karte 1:25,000) with most of the map sheets dated from 2004 (and hereafter referred to accordingly). The hedgerow network was digitised in a radius of $500 \mathrm{~m}$ around the plots on both sets of maps to calculate the density in meters per hectare $(\mathrm{m} / \mathrm{ha})$. For linear landscape elements the length (or density) is a good representative for habitat area and connectivity (Holland and Fahrig 2000). There was a considerable loss in the density of hedgerows in the study area (Table 1). While the historical density amounts to $116 \mathrm{~m} / \mathrm{ha}$ on average, there was a mean loss of almost half of the density until today (47\%). Occasionally, the loss even exceeded $77 \%$ of the network. One single plot gained more hedgerows than it lost but the net gain was only $8 \mathrm{~m} / \mathrm{ha}$. An exemplary change can be seen in Fig. 2.

Additionally, the distance of the hedgerow plots to the closest forests (as a potential source of forest species populations) was measured in the historical and present landscapes. Only deciduous or mixed forests with a minimum size of 0.5 ha were considered. For the present landscape, we also measured the distance to the nearest ancient forest which was defined as already being present on the historical maps. Recent forest patches are known to be less species rich than ancient ones (Naaf and Kolk 2015) and therefore we also calculated the distance to the nearest ancient forest to control for the difference in source population quality. The distance to the nearest forest decreased over time from on average $664 \mathrm{~m}$ to $500 \mathrm{~m}$ (Table 1) which means that the study area in parts gained recent forest. At the same time, ancient forests were lost and the mean distance to the nearest ancient forest increased by $56 \mathrm{~m}$.

Forest species richness

All statistical analyses were carried out using $R$. To analyse which of the compiled habitat and landscape variables had an influence on the forest species richness in hedgerows we ran several Generalized Linear Models (GLMs) with Poisson distribution in a multi-model approach. The models were tested for collinearity based on the variance inflation factor (VIF) and all included variables had VIF $<2$ (Zuur et al. 2010). The dispersion parameters of the Poisson distribution ranged from 0.84 to 1.28 , meaning that there was neither over- nor underdispersion in the data and a simple Poisson distribution could be used. Additionally, a correlation matrix of all explanatory variables was created and the Pearson-correlation coefficients were tested for significance.

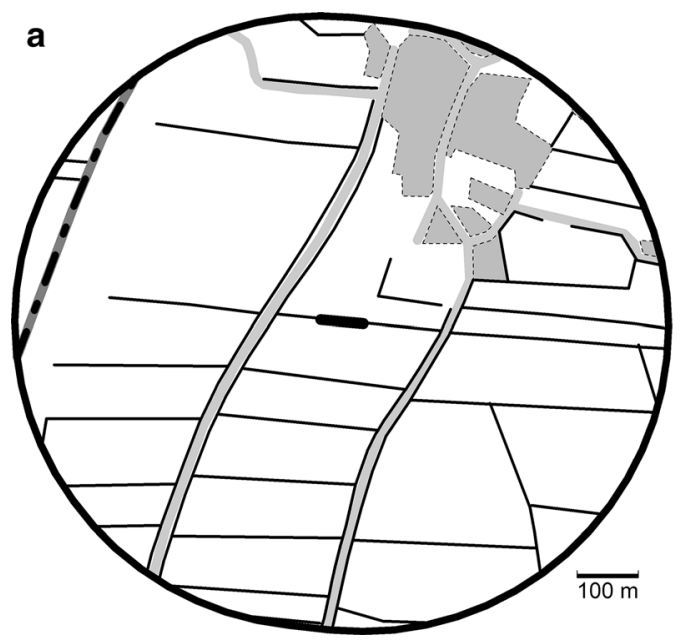

Fig. 2 One exemplary hedgerow network in a $500 \mathrm{~m}$ radius around the plot is shown for a the historical landscape (1877) and $\mathbf{b}$ the present landscape (2004). While there were only few

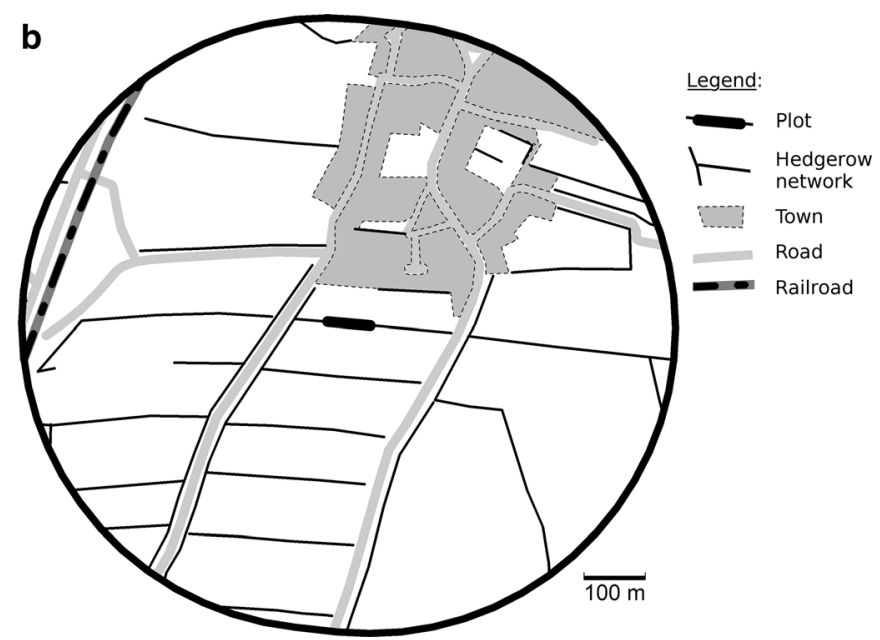

hedgerows created recently, large parts were cleared at the expense of the town and to gain larger agricultural fields. The density decreased from 114 to $83 \mathrm{~m} / \mathrm{ha}$ 
Similar to Kolk and Naaf (2015), we started with simple models that contained only one variable group (compare Table 1: $\mathrm{PL}=$ present landscape, PLAF $=$ present landscape with distance to nearest ancient forest, $\mathrm{HL}=$ historical landscape, HQ = habitat quality) and determined the Minimal Adequate Models (MAM) that contained only significant variables. We repeated this for the three complex models that each contained one of the landscape variable groups together with the habitat quality variables. This resulted in a list of seven models (four simple models and three complex models). The final AICs of each MAM were then compared to determine which set of variables best explained the found diversity patterns. A difference in the AIC was considered significant if it was larger than two. The same procedure was applied to model the richness of AWI species.

The best models were analysed further for both forest specialists and AWI species by assessing the remaining variables for their relative explanatory power by means of variance partitioning (varpart function in the 'vegan' package (Oksanen et al. 2019)).

\section{Results}

We found no difference between the present and the historical landscape in explaining today's forest species richness in hedgerows, i.e. no extinction debt (Table 2). Further, the complex models did not perform better than the simple models. In the simple models, the present and the historical density as well as the hedgerow width were all found significant. In all the complex models only the hedgerow width remained in the final models rendering it congruent with the habitat quality model. Even though hedgerow density was significant when entered on its own, in combination with the hedgerow width it provided no additional explanatory power and was thus excluded. Overall, the simple habitat quality model was the one with the lowest AIC ( $\triangle \mathrm{AIC}=10.35$ to the next best model) which means that the hedgerow width is the most important variable in explaining current species richness patterns. The wider the hedgerows were, the more forest specialists could be found in the hedgerows (Fig. 3).

In all the simple landscape models, the distance to the nearest forest was removed while the hedgerow density remained in the model. Therefore, the two models of the present landscape including either the shortest distance to any forest or the distance to the nearest ancient forest resulted in the same final model. As thus all final models contained only one variable, no variance partitioning was applied.

For the AWI species the results differed. Both for the simple and the complex approaches, the two superior models were those including the present landscape with the distance to the nearest ancient forest and the historical landscape, while overall the complex models performed best (Table 3). The habitat quality model had the highest AIC. More AWI species were found in hedgerows that were close to a forest in historical times, or close to one that was continuously present until today (and thus being ancient). The species richness of AWI species was, like overall

Table 2 Overview of the GLMs to analyse the effects of landscape and habitat variables on the forest specialist richness in hedgerows $(n=89)$

\begin{tabular}{|c|c|c|c|c|c|c|}
\hline & AIC & Intercept & Hedgerow density & Forest distance & Hedgerow width & $\mathrm{pH}$ value \\
\hline Present landscape & 426.41 & 2.274 & $-0.005 * *$ & - & & \\
\hline Historical landscape & 427.39 & 2.294 & $-0.003 * *$ & - & & \\
\hline Habitat quality & 416.06 & 1.249 & & & $0.159 * * *$ & - \\
\hline Landscape + habitat quality & 416.06 & 1.249 & - & - & $0.159 * * *$ & - \\
\hline
\end{tabular}

The AIC values are listed for each model. "Hedgerow density" and "Forest distance" refer to the respective variables of the specific model. For variables that remained in the minimal adequate model the estimates (log-transformed) and the significance levels are given $(* * * p \leq 0.001$, **0.001 $<p \leq 0.01, * 0.01<p \leq 0.05$ ). Variables that were removed from the models during model optimisation are crossed out. The final complex models were equivalent to the habitat quality model because the landscape variables were not significant. Also the present landscape models including the shortest distance to any forest or only the nearest ancient forest did not differ from another because forest distance was not significant in either of the models 


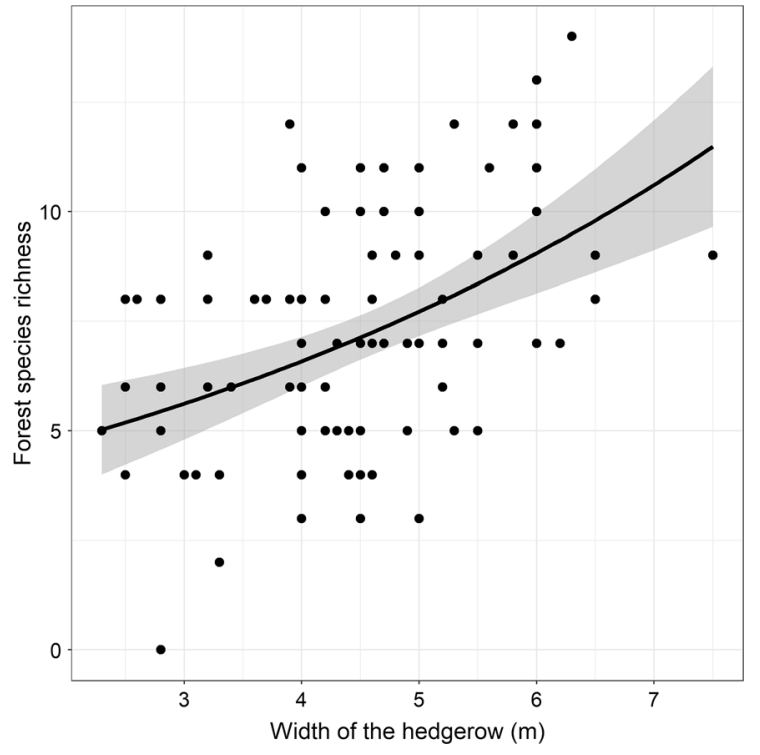

Fig. 3 Relationship between forest species richness and hedgerow width in hedgerow plots of $70 \mathrm{~m}$ length $(n=89)$. The curve is based on a Poisson distribution. The shaded area indicates the $95 \%$ confidence interval forest species richness, positively influenced by the width of the hedgerow. Overall, most of the variables remained in the final models.

Interestingly, a denser hedgerow network was negatively correlated to the number of forest species in the hedgerow, which may find its explanation in the correlation matrix of explanatory variables (Table 4). The hedgerow density is negatively correlated to the hedgerow width in both present and historical times. In addition, in historical times the hedgerow networks were denser when being further away from a forest. Today, this relationship can still be seen in the distance to the nearest ancient forest. That means that there are two covariates that result into the counter-intuitive negative correlation of network density and species richness.

Congruent results were seen in the variance partitioning for the AWI species. Most of the variation in AWI species richness was explained by the distance to the nearest forest for both of the best final models, i.e. the complex present landscape model with distance to

Table 3 Overview of the GLMs to analyse the effects of landscape and habitat variables on the species richness of ancient woodland indicators in hedgerows $(n=89)$

\begin{tabular}{|c|c|c|c|c|c|c|}
\hline & AIC & Intercept & Hedgerow density & Forest distance & Hedgerow width & $\mathrm{pH}$ value \\
\hline $\begin{array}{l}\text { Present landscape } \\
\text { (distance to any forest) }\end{array}$ & 256.05 & 1.713 & $-0.017 * * *$ & $-0.0011 * * *$ & & \\
\hline $\begin{array}{l}\text { Present landscape } \\
\text { (distance to ancient forests) }\end{array}$ & 252.87 & 1.745 & $-0.016^{* * *}$ & $-0.0009 * * *$ & & \\
\hline Historical landscape & 253.99 & 1.631 & $-0.009 * * *$ & $-0.0003 * *$ & & \\
\hline Habitat quality & 266.25 & -2.424 & & & $0.307 * * *$ & $0.297 * *$ \\
\hline $\begin{array}{l}\text { Present landscape } \\
\text { (distance to any forest) } \\
+ \text { Habitat quality }\end{array}$ & 253.64 & 0.643 & $-0.014 * *$ & $-0.0011^{* *}$ & $0.191 *$ & - \\
\hline $\begin{array}{l}\text { Present landscape } \\
\text { (distance to ancient forests) } \\
+ \text { Habitat quality }\end{array}$ & 246.94 & 0.330 & $-0.012 * *$ & $-0.0010 * * *$ & $0.262 * *$ & - \\
\hline $\begin{array}{l}\text { Historical landscape } \\
+ \text { Habitat quality }\end{array}$ & 247.92 & 0.126 & $-0.006 * *$ & $-0.0010^{* * *}$ & $0.272 * *$ & - \\
\hline
\end{tabular}

The AIC values are listed for each model. "Hedgerow density" and "Forest distance" refer to the respective variables of the specific model. For variables that were included in the minimal adequate model the estimates (log-transformed) and the significance levels are given $(* * * p \leq 0.001, * * 0.001<p \leq 0.01, * 0.01<p \leq 0.05)$. Variables that were removed from the models during model optimisation are crossed out 
Table 4 Correlation matrix of variables included in the models

\begin{tabular}{|c|c|c|c|c|}
\hline & Present hedgerow density & Historical hedgerow density & Hedgerow width & $\mathrm{pH}$ \\
\hline Historical distance to nearest forest & $0.24 *$ & $0.39 * * *$ & -0.09 & $-0.22 *$ \\
\hline Present distance to nearest forest & 0.18 & $0.26^{*}$ & -0.11 & -0.19 \\
\hline Present distance to nearest ancient forest & $0.21 *$ & $0.34 * *$ & 0.08 & -0.19 \\
\hline Hedgerow width & $-0.29 * *$ & $-0.27 *$ & - & -0.01 \\
\hline $\mathrm{pH}$ & 0.03 & -0.02 & -0.01 & - \\
\hline
\end{tabular}

The values given are Pearson correlation coefficients with their significance levels $(* * * p \leq 0.001$, **0.001 $<p \leq 0.01$, $* 0.01<p \leq 0.05)$. $n=89$. The italised coefficients of the landscape variables are included for informative reasons but are not used together in one model

the nearest ancient forest and the complex historical landscape model. The distance accounted for $38 \%$ and $24.3 \%$, respectively, of the explained variation. The hedgerow width explained $22.5 \%$ and $21.5 \%$ and the hedgerow density another $13.4 \%$ and $13.2 \%$, respectively. The strong overlap of the hedgerow density with other variables is expressed in the high proportion of shared variation: $16.5 \%$ and $31 \%$ in combination with the respective forest distance and $18.4 \%$ and $19.3 \%$, respectively, with the shrub width. The variation shared between all three variables was less than $1 \%$ for both models.

\section{Discussion}

Covariates obscure the species-area relationship

We found no indication for an extinction debt of forest specialists in hedgerows. The models including the historical landscape configuration did not outcompete the models for the present landscape. Instead, the habitat quality, represented by the width of the shrub layer, was the best model in explaining the patterns of forest species richness found today. This underlines the importance of integrating local effects into landscape models. Forest plant species can display an extinction debt as evidenced in other studies from forest fragments (Paltto et al. 2006; Vellend et al. 2006). But even though hedgerows are wooded habitats, they differ from forests in some important aspects. Because of their linear structure, hedgerows have a high edge-to-area ratio, are prone to strong fluctuations in temperature and humidity and face frequent disturbances caused by the adjacent land use.
With increasing width this effect is mitigated which causes the microclimate to be more stable and increasingly similar to forests (Vanneste et al. 2020). This is in accordance with many studies which found hedgerow width to be essential for forest plants (e.g. Forman and Baudry 1984; Le Cœur et al. 1997; Roy and de Blois 2008; Closset-Kopp et al. 2016; Litza and Diekmann 2019). Deckers et al. (2004) found structural variables such as hedgerow width, length and height to be more important for the species richness than spatial variables such as distance to the nearest forest and the density of the hedgerow network. Roy and de Blois (2008) described hedgerow width to be the most important local variable for forest specialists but also found a positive effect of the nearby forest cover and hedgerow age. Ernoult and Alard (2011) studied the influence of landscape configuration at different spatial and temporal scales on hedgerow species richness and report an effect of past adjacent land-use and network connectivity.

The strong influence of hedgerow width might also explain why we found more forest specialists in sparser networks. There was a negative correlation between the density of the hedgerow network and the width of the hedgerows, and it is thus possible to link the density of a network to differences in habitat quality. Because of this strong correlation, we believe that the hedgerow width is not only a local variable but can also function as a proxy for habitat quality on a landscape scale. This relationship has already been described early on in hedgerow research by Marquardt (1950) who explained this phenomenon with the land loss that resulted from the construction of hedgerows. Areas that were dominated by manorialism and thus divided into large manors had always had larger fields 
and thus a lower hedgerow density. Peasantry-dominated areas on the other hand were divided into many small fields that all had to be enclosed with hedgerows. When farmers owned less land they tried to keep the hedgerow banks as narrow as possible to save farmable land (Marquardt 1950). Large landowners in contrast could afford to keep wider hedgerows. In this way, the construction of less dense networks often resulted in a higher habitat quality.

The hedgerow density also depends on the soil quality as soils with lower quality are often associated with larger fields (Marquardt 1950). At the same time areas with low soil quality were not clear cut for agriculture (Behre 2008). Thus networks around (ancient) forests are likely to be less dense. Another aspect is related to differences in the age of networks of different densities. Hedgerows on the land of manors were often created before the enclosure movement (i.e. before the eighteenth century) and are therefore likely older than hedgerows in the dense, well-structured networks of later times (Weber 2003). Litza and Diekmann (2019) indeed found more forest specialists in ancient hedgerows (created before 1877) but it can be assumed that the colonisation credit of the hedgerows from the times of the enclosure was already paid off and that there is no difference between these hedgerows and older ones. Depending on the proximity of source populations Litza and Diekmann (2019) found that the colonisation credit in recent hedgerows could be paid off within several decades.

Overall, the hedgerow density integrates several covariates and thus represents a complex set of variables and not mainly, as expected, habitat area and connectivity. This obscures the species-area relationship which in turn hampers the analysis of an extinction debt. This problem was not caused by the sampling method or the statistical analysis but instead is an inherent problem of the specific data set and thus cannot be overcome with the usual statistical approaches.

\section{Extinction debt for ancient woodland indicator} species

Despite the overall difficulties, we found historical patterns to be more important for ancient woodland indicator (AWI) species richness than present patterns suggesting an extinction debt. This emphasises the importance of investigating relevant subgroups of species as these may respond differently to landscape compositional changes (Adriaens et al. 2006; Van den Berge et al. 2018). Also for AWI species the speciesarea relationship was inversely proportional, however, the variable most influential for AWI species richness was the proximity to forests. Here it is important to note that the distance to the nearest forest actually decreased over time because new forests were planted on former agricultural land. The improvement of habitat conditions is again an uncommon phenomenon in extinction debt studies. However, recent forests are in general less species rich than ancient forests (Kolk et al. 2017) and thus represent less potent source populations. The average distance to ancient forests actually increased because some of those particularly species rich forests were destructed. AWI species have very low dispersal capacities and therefore depend on the close proximity to potent source populations (Wulf 2003). Our results reflect this because even though the forest distance was significant in both models of the present landscape, the model including the distance to the nearest ancient forest performed considerably better. This confirms that species with different dispersal capacities are differently affected by a change in landscape composition and patch configuration.

Implications for management

We found no evidence for a general extinction debt for forest plants in hedgerows but owing to the strong influence of several covariates on hedgerow density we cannot exclude its presence. Therefore, we do not know how the loss of surrounding habitat affected the forest plant community. Hedgerows are a very dynamic habitat with a high edge-to-area ratio. It is therefore conceivable that the fragmentation per se has a negligible effect. But the loss of habitat area is likely to have reduced the carrying capacity of the habitat and to have resulted in declining species numbers. Whether this happened immediately or over time cannot be concluded from our data. The extinction debt found for ancient woodland indicator species was mainly caused by the different distances to ancient forests in the surrounding when comparing the historic and present landscapes. This highlights the importance of conserving ancient woodlands as biodiversity hotspots and potential source populations on a landscape level. 
We conclude that the quality of the habitat is more important for forest plants in hedgerows than the decline in the hedgerow network. For management and conservation this does not imply that the remaining hedgerows do not need to be protected but instead that an even stronger focus needs to be put on the habitat quality and the width of the hedgerows in particular. The decline in the hedgerow network was severe over the last century but was halted in recent years when stricter management regulations were introduced. Potential land loss is used as an argument against maintaining hedgerows and there is still a tendency of land-owners of keeping the hedgerows as narrow as possible when less agricultural land is available. This is very unfortunate because the hedgerow width was confirmed to be a key element for the habitat quality.

Acknowledgements Open Access funding provided by Projekt DEAL. The authors would like to thank GeoGREIF, the Schleswig-Holsteinische Landesbibliothek and the Landesamt für Landwirtschaft, Umwelt und ländliche Räume (LLUR) for the historical maps. In addition, we thank the LLUR for providing the latest maps.

Open Access This article is licensed under a Creative Commons Attribution 4.0 International License, which permits use, sharing, adaptation, distribution and reproduction in any medium or format, as long as you give appropriate credit to the original author(s) and the source, provide a link to the Creative Commons licence, and indicate if changes were made. The images or other third party material in this article are included in the article's Creative Commons licence, unless indicated otherwise in a credit line to the material. If material is not included in the article's Creative Commons licence and your intended use is not permitted by statutory regulation or exceeds the permitted use, you will need to obtain permission directly from the copyright holder. To view a copy of this licence, visit http://creativecommons.org/licenses/by/4.0/.

\section{References}

Adriaens D, Honnay O, Hermy M (2006) No evidence of a plant extinction debt in highly fragmented calcareous grasslands in Belgium. Biol Conserv 133:212-224

Behre K-E (2008) Landschaftsgeschichte Norddeutschlands. Umwelt und Siedlung von der Steinzeit bis zur Gegenwart, Wachholtz, Neumünster

Bivand R, Rundel C (2018) rgeos: interface to geometry engine-Open Source ('GEOS') (version 0.3-27). https:// CRAN.R-project.org/package $=$ rgeos. Accessed 1 June 2018
Brunet J, Valtinat K, Mayr ML, Felton A, Lindbladh M, Bruun HH (2011) Understory succession in post-agricultural oak forests: Habitat fragmentation affects forest specialists and generalists differently. For Ecol Manage 262:1863-1871

Closset-Kopp D, Wasof S, Decocq G (2016) Using processbased indicator species to evaluate ecological corridors in fragmented landscapes. Biol Conserv 201:152-159

Corbit M, Marks PL, Gardescu S (1999) Hedgerows as habitat corridors for forest herbs in central New York, USA. J Ecol $87: 220-232$

Cousins SAO, Ohlson H, Eriksson O (2007) Effects of historical and present fragmentation on plant species diversity in semi-natural grasslands in Swedish rural landscapes. Landsc Ecol 22:723-730

Critchley CNR, Wilson LA, Mole AC, Norton LR, Smart SM (2013) A functional classification of herbaceous hedgerow vegetation for setting restoration objectives. Biodivers Conserv 22:701-717

Deckers B, Hermy M, Muys B (2004) Factors affecting plant species composition of hedgerows: relative importance and hierarchy. Acta Oecol 26:23-37

Deckers B, Kerselaers E, Gulinck H, Muys B, Hermy M (2005) Long-term spatio-temporal dynamics of a hedgerow network landscape in Flanders, Belgium. Environ Conserv 32:20-29

Dirzo R, Raven PH (2003) Global state of biodiversity and loss. Annu Rev Environ Resour 28:137-167

DWD (2015) Temperatur: vieljährige Mittelwerte 1981-2010. Aktueller Standort. Deutscher Wetterdienst. https://www. dwd.de/DE/leistungen/klimadatendeutschland/ mittelwerte/temp_8110_akt_html.html. Accessed 25 Mar 2019

Endels P, Adriaens D, Verheyen K, Hermy M (2004) Population structure and adult plant performance of forest herbs in three contrasting habitats. Ecography 27:225-241

Ernoult A, Alard D (2011) Species richness of hedgerow habitats in changing agricultural landscapes: are alpha and gamma diversity shaped by the same factors? Landsc Ecol 26:683-696

Fahrig L (2003) Effects of habitat fragmentation on biodiversity. Annu Rev Ecol Evol Syst 34:487-515

Forman RTT, Baudry J (1984) Hedgerows and hedgerow networks in landscape ecology. Environ Manage 8:495-510

Glaser FF, Hauke U (2004) Historisch alte Waldstandorte und Hudewälder in Deutschland. Ergebnisse bundesweiter Auswertungen, vol 61. Angewandte Landschaftökologie, Bundesamt für Naturschutz, Bonn

Holland J, Fahrig L (2000) Effect of woody borders on insect density and diversity in crop fields: a landscape-scale analysis. Agric Ecosyst Environ 78:115-122

Jackson ST, Sax DF (2010) Balancing biodiversity in a changing environment: extinction debt, immigration credit and species turnover. Trends Ecol Evol 25:153-160

Jungelt M (2016) Schätzung der Knicklänge in SchleswigHolstein aus den Daten des HNV-Farmland-Monitorings. Landesamt für Landwirtschaft Umwelt und ländliche Räume Schleswig-Holstein, Flintbek

Kellerhoff J (1984) Flurbereinigung. Anspruch und Wirklichkeit, vol 1. Natur-Dokumente BIOlogik Verlag, Saerbeck 
Kolb A (2008) Habitat fragmentation reduces plant fitness by disturbing pollination and modifying response to herbivory. Biol Conserv 141:2540-2549

Kolk J, Naaf T (2015) Herb layer extinction debt in highly fragmented temperate forests-completely paid after 160 years? Biol Conserv 182:164-172.

Kolk J, Naaf T, Wulf M (2017) Paying the colonization credit: converging plant species richness in ancient and postagricultural forests in NE Germany over five decades. Biodivers Conserv 26:735-755

Kuussaari M, Bommarco R, Heikkinen RK, Helm A, Krauss J, Lindborg R, Öckinger E, Pärtel M, Pino J, Rodà F, Stefanescu C, Teder T, Zobel M, Steffan-Dewenter I (2009) Extinction debt: a challenge for biodiversity conservation. Trends Ecol Evol 24:564-571

Le Cœur D, Baudry J, Burel F (1997) Field margins plant assemblages: variation partitioning between local and landscape factors. Landsc Urban Plann 37:57-71

Litza K, Diekmann M (2017) Resurveying hedgerows in Northern Germany: plant community shifts over the past 50 years. Biol Conserv 206:226-235

Litza K, Diekmann M (2019) Hedgerow age affects the species richness of herbaceous forest plants. J Veg Sci 30:553-563

Marquardt G (1950) Die schleswig-holsteinische Knicklandschaft. Schrift Geogr Inst Univ Kiel 13:1-90

MELUR (2017) Durchführungsbestimmungen zum Knickschutz. Ministerium für Energiewende, Landwirtschaft, Umwelt und ländliche Räume des Landes SchleswigHolstein (MELUR), Kiel

MLUR (2005) Landschafatselementekataster: Erfasste Knick/ Feldheckenlängen im Rahmen der Luftbildauswertung auf Basis der CIR-Invekos-Befliegung 2004. Ministerium für Landwirtschaft Umwelt und ländliche Räume (MLUR), Kiel

Müller G (2013) Europas Feldeinfriedungen: Wallhecken (Knicks), Hecken, Feldmauern (Steinwälle), Trockenstrauchhecken, Biegehecken, Flechthecken, Flechtzäune und traditionelle Holzzäune. Neuer Kunstverlag, Stuttgart

Naaf T, Kolk J (2015) Colonization credit of post-agricultural forest patches in NE Germany remains 130-230 years after reforestation. Biol Conserv 182:155-163

Oksanen J, Blanchet FG, Friendly M, Kindt R, Legendre P, McGlinn D, Minchin PR, O'Hara RB, Simpson GL, Solymos P, Stevens MHH, Szoecs E, Wagner H (2019) vegan: community ecology package (version 2.5-5). https://CRAN.R-project.org/package=vegan. Accessed 15 July 2019

Paal T, Kütt L, Lõhmus K, Liira J (2017) Both spatiotemporal connectivity and habitat quality limit the immigration of forest plants into wooded corridors. Plant Ecol 218:417-431

Paltto H, Norden B, Gotmark F, Franc N (2006) At which spatial and temporal scales does landscape context affect local density of Red Data Book and indicator species? Biol Conserv 133:442-454

Pollard E, Hooper MD, Moore NW (1974) Hedges. William Collins Sons \& Co Ltd, London

Poschlod P, Braun-Reichert R (2017) Small natural features with large ecological roles in ancient agricultural landscapes of Central Europe-history, value, status, and conservation. Biol Conserv 211:60-68
QGIS Development Team (2016) QGIS geographic information system: Open Source Geospatial Foundation. https://qgis. org. Accessed 15 Feb 2017

Roy V, de Blois S (2008) Evaluating hedgerow corridors for the conservation of native forest herb diversity. Biol Conserv 141:298-307

Sala OE, Chapin FS, Armesto JJ, Berlow E, Bloomfield J, Dirzo R, Huber-Sanwald E, Huenneke LF, Jackson RB, Kinzig A, Leemans R, Lodge DM, Mooney HA, Oesterheld M, Poff NL, Sykes MT, Walker BH, Walker M, Wall DH (2000) Biodiversity - Global biodiversity scenarios for the year 2100. Science 287:1770-1774

Schmidt M, Kriebitzsch W-U, Ewald J (2011) Waldartenliste der Farn- und Blütenpflanzen, Moose und Flechten Deutschlands. BfN-Skripten 299:1-111

Schmidt M, Molder A, Schonfelder E, Engel F, Schmiedel I, Culmsee H (2014) Determining ancient woodland indicator plants for practical use: a new approach developed in northwest Germany. For Ecol Manage 330:228-239

Sitzia T (2007) Hedgerows as corridors for woodland plants: a test on the Po Plain, Northern Italy. Plant Ecol 188:235-252

Staley JT, Bullock JM, Baldock KCR, Redhead JW, Hooftman DAP, Button N, Pywell RF (2013) Changes in hedgerow floral diversity over 70 years in an English rural landscape, and the impacts of management. Biol Conserv 167:97-105

Stamm SV, Welters A (1996) Zur Geschichte der schleswigholsteinischen Knicks. EcoSyst Beitr Z Ökosystemforschung 5:11-22

Nord S (2018) Statistische Berichte. Bodenflächen in Schleswig-Holstein am 31.12.2016 nach Art der tatsächlichen Nutzung. Statistisches Amt für Hamburg und SchleswigHolstein, Hamburg

Tilman D, May RM, Lehman CL, Nowak MA (1994) Habitat destruction and the extinction debt. Nature 371:65-66

Van den Berge S, Baeten L, Vanhellemont M, Ampoorter E, Proesmans W, Eeraerts M, Hermy M, Smagghe G, Vermeulen I, Verheyen K (2018) Species diversity, pollinator resource value and edibility potential of woody networks in the countryside in northern Belgium. Agric Ecosyst Environ 259:119-126

Van Vooren L, Reubens B, Broekx S, Frenne PD, Nelissen V, Pardon P, Verheyen K (2017) Ecosystem service delivery of agri-environment measures: a synthesis for hedgerows and grass strips on arable land. Agric Ecosyst Environ 244:32-51

Vanneste T, Govaert S, Spicher F, Brunet J, Cousins SAO, Decocq G, Diekmann M, Graae BJ, Hedwall P-O, Kapás RE, Lenoir J, Liira J, Lindmo S, Litza K, Naaf T, Orczewska A, Plue J, Wulf M, Verheyen K, De Frenne P (2020) Contrasting microclimates among hedgerows and woodlands across temperate Europe. Agricult For Meteorol 281:107818

Vellend M, Verheyen K, Jacquemyn H, Kolb A, Van Calster H, Peterken G, Hermy M (2006) Extinction debt of forest plants persists for more than a century following habitat fragmentation. Ecology 87:542-548

Weber HE (1967) Über die Vegetation der Knicks in SchleswigHolstein Teil 1 (Text), vol 15. Mitteilungen der Arbeitsgemeinschaft für Floristik in Schleswig-Holstein und Hamburg, Kiel 
Weber HE (2003) Gebüsche, Hecken Krautsäume. Ökosysteme Mitteleuropas aus geobotanischer Sicht Ulmer, Stuttgart

Wehling S, Diekmann M (2009a) Hedgerows as an environment for forest plants: a comparative case study of five species. Plant Ecol 204:11-20

Wehling S, Diekmann M (2009b) Importance of hedgerows as habitat corridors for forest plants in agricultural landscapes. Biol Conserv 142:2522-2530

Wulf M (2003) Preference of plant species for woodlands with differing habitat continuities. Flora 198:444-460
Zuur AF, Ieno EN, Elphick CS (2010) A protocol for data exploration to avoid common statistical problems. Methods Ecol Evol 1:3-14.

Publisher's Note Springer Nature remains neutral with regard to jurisdictional claims in published maps and institutional affiliations. 